\title{
Amphibia, Anura, Strabomantidae, Strabomantis aramunha Cassimiro, Verdade and Rodrigues, 2008: Distribution extension with notes on natural history, color patterns, and morphometric data
}

\author{
Marcelo Felgueiras Napoli ${ }^{1 *}$, Flora Acuña Juncá ${ }^{2}$, Deise Cruz ${ }^{1}$ and Rafael Oliveira de Abreu ${ }^{1}$ \\ 1 Universidade Federal da Bahia, Instituto de Biologia, Departamento de Zoologia, Museu de Zoologia. Campus Universitário, Rua Barão de \\ Jeremoabo, Ondina. CEP 40170-115, Salvador, BA, Brazil. \\ 2 Universidade Estadual de Feira de Santana, Departamento de Ciências Biológicas. Campus Universitário, Avenida Universitária. CEP 44031-060. \\ Feira de Santana, BA, Brazil. \\ * Corresponding author e-mail: napoli@ufba.br
}

\begin{abstract}
During surveys of anurans in the Chapada Diamantina, a semiarid region in central Bahia, Brazil, we obtained new records of Strabomantis aramunha Cassimiro, Verdade and Rodrigues. The new records extend the geographic distribution of $S$. aramunha in about $200 \mathrm{~km}$ north and $75 \mathrm{~km}$ south in relation to the type locality (municipality of Mucugê, state of Bahia, Brazil). We observed males calling at night at the Morro do Pai Inácio, municipality of Palmeiras. This new data is important, as in the original description the authors suggested the possibility of absence of advertisement call in the species. We also provide additions on color and morphometric data.
\end{abstract}

The genus Strabomantis Peters, 1863 is currently allocated in Strabomantidae Hedges, Duellman and Heinicke, 2008, and comprises 17 species of forestlitter dweller frogs, occurring from Costa Rica through Colombia, Ecuador, Peru, Amazon basin and central Bahia state in Brazil (Frost 2009). Strabomantis aramunha Cassimiro, Verdade and Rodrigues, 2008 (Figure 1) is known only from its type locality, Municipality of Mucugê, state of Bahia, Brazil, that lies in the Serra do Sincorá, a regional designation of the Serra do Espinhaço mountain range. The original description of Strabomantis aramunha was based in only 7 specimens from the same place $(2$ adult males, 2 adult females, 2 juvenile females, 1 juvenile male), presented a short description of color in life and preservative, few data on natural history, and there was no information about its advertisement call (Cassimiro et al. 2008). During surveys of anurans in the municipalities of Miguel Calmon ( $11^{\circ} 22^{\prime} \mathrm{S}, 40^{\circ} 31^{\prime} \mathrm{W}, 763 \mathrm{~m}$ above sea

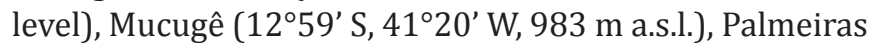
(12 ${ }^{\circ} 27^{\prime} \mathrm{S}, 41^{\circ} 28^{\prime} \mathrm{W}$; $12^{\circ} 31^{\prime} \mathrm{S}, 4^{\circ} 33^{\prime} \mathrm{W}$; $1200 \mathrm{~m}$ a.s.l.), Lençóis (12 ${ }^{\circ} 33^{\prime} \mathrm{S}, 41^{\circ} 23^{\prime} \mathrm{W}, 643 \mathrm{~m}$ a.s.l.), Iraquara (12¹4'

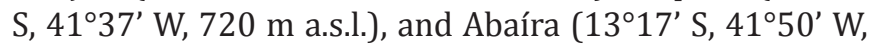
$1195 \mathrm{~m}$ a.s.l.), all located in the state of Bahia, Brazil, we obtained new records and data on S. aramunha, which will be described herein.

We captured and analyzed 28 specimens of Strabomantis aramunha from six localities in the state of Bahia, Brazil (five representing new records), that are deposited in the Brazilian herpetological collections of the Museu de Zoologia da Universidade Federal da Bahia (UFBA) and Museu de Zoologia da Universidade Estadual de Feira de Santana (MZUEFS), as follows - BRAZIL: state of Bahia: Municipality of Abaíra: MZUEFS 1789, juvenile (undetermined gender), Catolés de Cima, Serra do Tijuquinha, collected by Flora A. Juncá, on 14 February 2004. Municipality of Iraquara: MZUEFS 2739, juvenile female, Fazenda Mata Verde, collected by Rosangela Andrade, on 23 May 2007. Municipality of Lençóis: MZUEFS 1555, adult male, borders of the BA-242 road, collected by Leila Pessoa, on 26 July 2003. Municipality of Miguel Calmon, Parque Estadual das Sete Passagens: UFBA 6221-6222, adult females, collected by Ariane L.

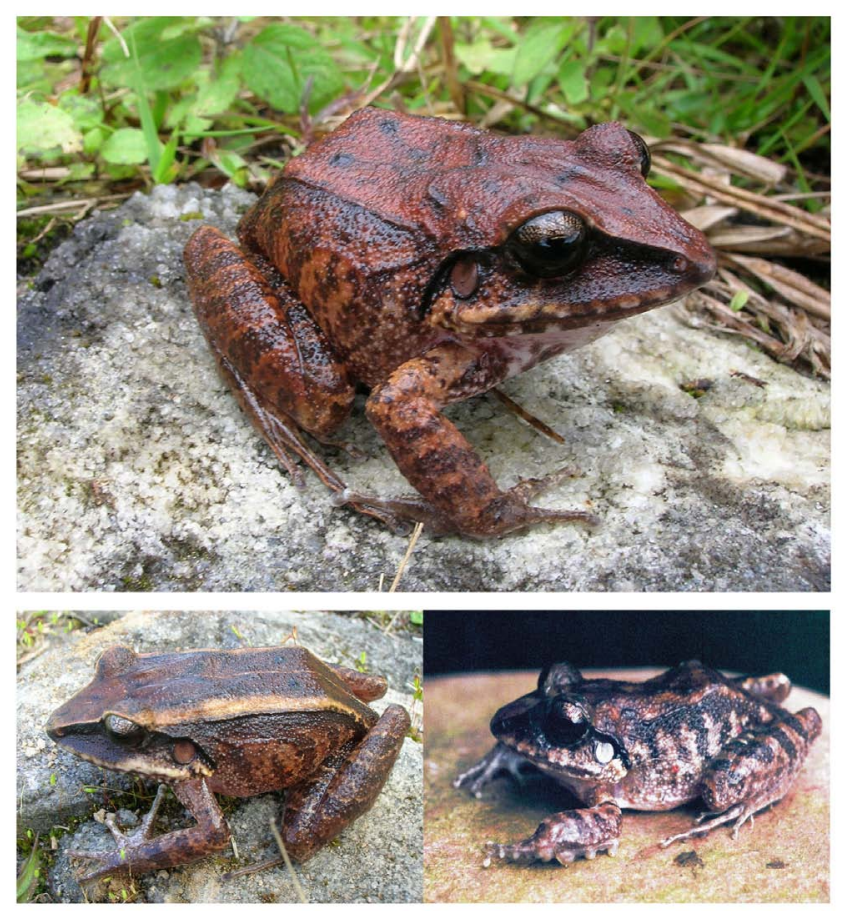

FigurE 1. Living specimens of Strabomantis aramunha from the state of Bahia, Brazil. Above, UFBA 6221, adult female, SVL $66.1 \mathrm{~mm}$; underneath left, UFBA 6222, SVL $64.0 \mathrm{~mm}$, adult female, showing a dorsal color pattern characterized by two cream longitudinal dorsolateral stripes; both specimens from the Parque Estadual das Sete Passagens, municipality of Miguel Calmon (photos by Rafael O. Abreu). Underneath right, adult male, not captured, from the Parque Municipal de Mucugê, state of Bahia, Brazil (photo by Flora A. Juncá). 
Xavier, Patricia M. Fonseca, and Deise Cruz, on 22-25 July 2006; UFBA 6383-6384, adult females, from Vale do Jajai, collected by Ariane L. Xavier, Deise Cruz, Milena Camardelli, Patricia M. Fonseca, and Rafael O. Abreu, on 23-26 July 2006; UFBA 6729, adult male, UFBA 6730, juvenile female, and UFBA 6731, juvenile (undetermined gender), collected by Ariane L. Xavier, Deise Cruz, Milena Camardelli, Patricia M. Fonseca, Rafael O. Abreu, and Wilton Fahning, on 18-23 November 2006. Municipality of Mucugê, Parque Municipal de Mucugê: MZUEFS 2194, adult female, collected by Ednei Mercês, on 26 January 2006; MZUEFS 2360, adult female, and MZUEFS 2361, adult male, collected by Alessandra Santana, on 22 March 2006; MZUEFS 2368, adult female, collected by Flora A. Juncá, on 25 May 2006; MZUEFS 2376, adult female, collected by Flora A. Juncá, on 19 April 2006; MZUEFS 2377, adult female, collected by Alessandra Santana, on 20 April 2006; MZUEFS 2380, adult male, collected by Alessandra Santana, on 01 September 2006; MZUEFS 2382, adult female, collected by Flora A. Juncá, on 22 September 2006; UFBA 5971, adult female, from Rio Piabinha, collected by Priscila C. A. Cardoso, on 23 August 2005; UFBA 7384, juvenile (undetermined gender), collected by Moacir S. Tinôco, on 16 December 2003; UFBA 7766, adult female, collected by Patricia M. Fonseca and Milena Camardelli, on 11 April 2006. Municipality of Palmeiras: MZUEFS 269, adult female, collected by Luciana Lugli, on 19 March de 1999; Cachoeira da Fumaça: MZUEFS 1895, adult male, collected by Luciana Lugli, on 25 March 2001; Morro do Pai Inácio: MZUEFS 2124, adult female, and MZUEFS 2125-2126, 2129, adult males, collected by Alessandra Santana, Maria Lúcia Del Grande, and Roseane Santiago, respectively, on 23 September 2005; MZUEFS 2369, adult male, collected by Flora A. Juncá, on 26 June 2006. The Instituto Brasileiro do Meio Ambiente e dos Recursos Naturais Renováveis (IBAMA) permitted collection of specimens (license number 02006.002336/03-26, 0210.000812/05-84, and 02010.002784/05-30).

Environmentand conservation: The ChapadaDiamantina Ecoregion is characterized by mountain ranges with altitudes varying from 600 to $2033 \mathrm{~m}$ (highest point of the state of Bahia), and is comprised in the Brazilian semiarid region. The mountain scenery contains ecosystems like 'caatinga', 'cerrado', 'campo rupestre', deciduous and semi deciduous mountain forests, and gallery forests. Strabomantis aramunha occurs in three protected areas: the Parque Nacional da Chapada Diamantina, comprising the municipalities of Lençóis, Palmeiras and Mucugê; the Parque Municipal de Mucugê, municipality of Mucugê; and the Parque Estadual das Sete Passagens, municipality of Miguel Calmon, all in the state of Bahia, Brazil. The species is currently categorized as data deficient by the IUCN red list of threatened species (Cassimiro 2009).

Distribution extension and notes on natural history. The new records extend the geographic distribution of Strabomantis aramunha in about $200 \mathrm{~km}$ north and 75 $\mathrm{km}$ south in relation to the type locality (municipality of Mucugê, state of Bahia, Brazil; Figure 2). Strabomantis aramunha wascapturedin open areas of savannawoodlands ('cerrados'), in rocky mountain fields known as 'campos rupestres', a typical environment in Chapada Diamantina (for description of 'campo rupestre' see Rizzini 1979), and in semi-deciduous forest environments surrounded by 'campos rupestres', within altitudes ranging from 800 to $1200 \mathrm{~m}$ above sea level. Males (MZUEFS 2124-2126) were observed on October 2006 calling at night, on the ground, surrounded by herbaceous vegetation, at the Morro do Pai Inácio, municipality of Palmeiras. This new data is
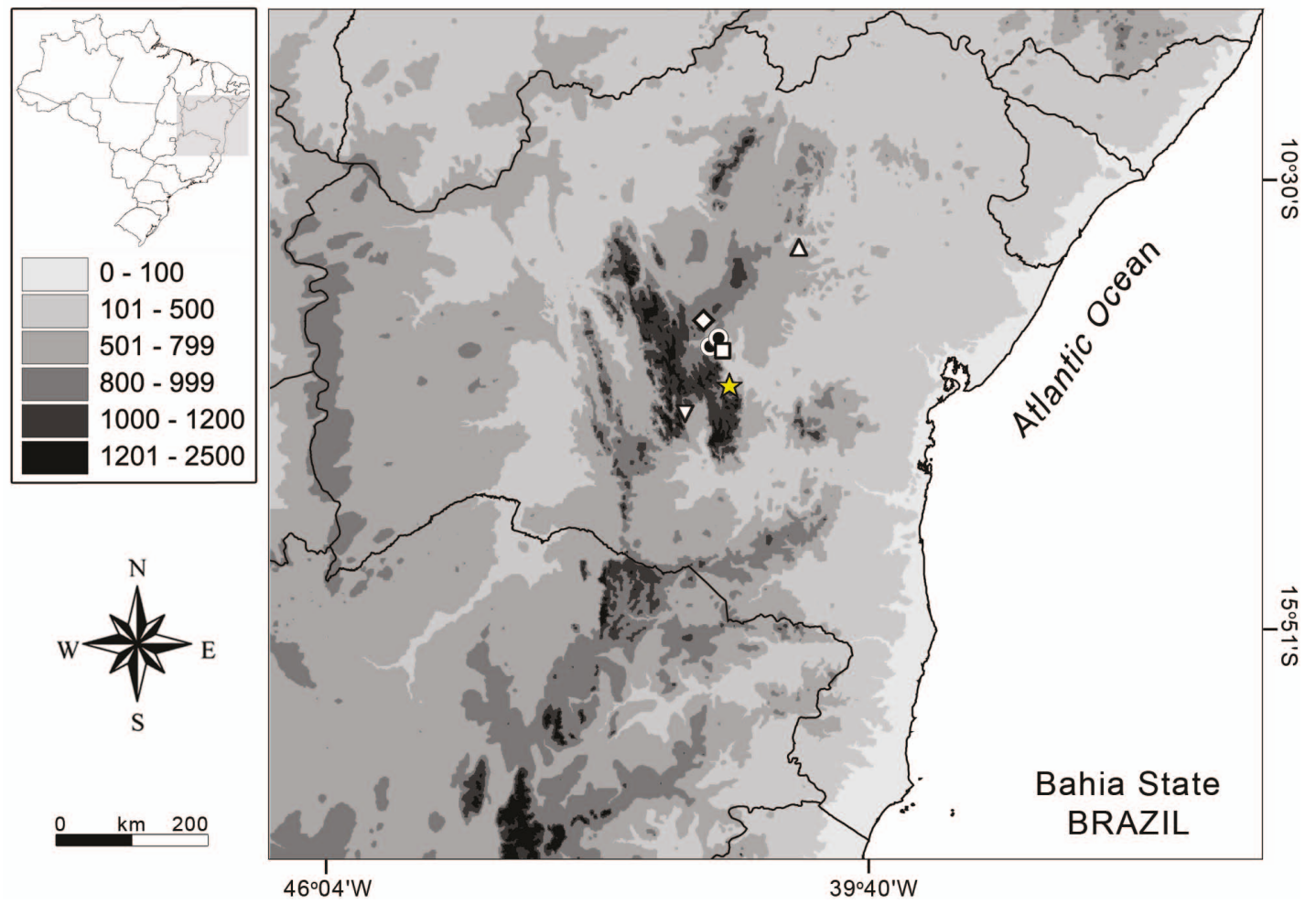

FIGURE 2. Geographic distribution of Strabomantis aramunha on topographic map. Star, municipality of Mucugê, type locality; new records within the Chapada Diamantina Ecoregion, state of Bahia, Brazil: triangle, Miguel Calmon; lozenge, Iraquara; circle, Palmeiras; square, Lençóis; inverted triangle, Abaíra. 
important, as Cassimiro et al. (2008) in the original species description stated that they did not hear specimens of $S$. aramunha calling, and suggested the possibility of absence of advertisement call in the species, as it is not infrequent among eleutherodactylines. Strabomantis aramunha was found in syntopy with Bokermannohyla diamantina (only in the municipality of Abaíra), Bokermannohyla itapoty, Bokermannohyla oxente, Hypsiboas faber, Ischnocnema aff. ramagii, Leptodactylus furnarius, Physalaemus cuvieri, Odontophrynus americanus (only in the municipality of Abaíra), Proceratophrys aff. cristiceps, Rupirana cardosoi, Scinax sp. (S. ruber group), and Scinax aff. duartei.

Additions on color and morphometric data: In preservative, dorsal surfaces brown or dark brown, with a narrow blackish brown interorbital stripe (Figures 3-5); snout with two mid-line blackish brown dots, a smaller one near the tip of snout, and the other near eyes; canthus rostralis delimited above by a light cream stripe from tip of snout to outer edge of upper eyelid, and below by a broad blackish-brown stripe; lorus tan or dark brown; upper lip cream with dark brown markings, somewhat anastomosed; dark brown oblique bars may be present under eye; supratympanic fold marked below by a broad blackish-brown stripe; tympanum light tan; a pair of faint to blackish brown spots above sacral region; a pair of $\wedge$-shaped blackish-brown spots behind the head, above shoulder girdle region; a pair of blackish-brown dorsolateral folds, from the upper eyelid, or from behind the shoulder, to near the groin; some specimens with a second granular ridge, more internal, somewhat oblique on back of head and $\rangle\langle$-shaped, more or less parallel to the former, and bordered by scant to numerous dark brown dots; in the latter case, a broad cream highlighted dorsolateral stripe from the upper eyelid to near the groin is present between dorsolateral ridges (Figure 5); a weak highlighted cream vertebral stripe may be present from the tip of snout to vent; additional faint brown markings are scattered over dorsum; forearms with two to three transverse dark brown bars; flank with background color cream to medium brown, often with four to five broad dark brown oblique bars; superior thigh surface with four to five broad dark brown bars intercalated with thinner lighter brown bars, somewhat continuous with the bars from the flank; anterior and posterior thigh surfaces uniform brown or almost immaculate; tarsus and sole of foot uniform tan brown; subarticular and supernumerary tubercles, and inner and outer metatarsal tubercles cream; ventral surfaces pale cream, with or without medium brown dots and blotches over it, mainly on arms, gular surface, chest, and margins of belly. In life, the general color follows that in preservative, but with more vivid dorsal background, varying from dark brown to dark reddish brown, and blackish brown dorsal marking (Figure 1). The morphometric data is summarized in Table 1.

TABLE 1. Descriptive statistics (in millimeters) of adult males and females of Strabomantis aramunha from the municipalities of Miguel Calmon, Mucugê, and Palmeiras, state of Bahia, Brazil, all in the Chapada Diamantina Ecorregion.

\begin{tabular}{|c|c|c|c|c|c|c|c|c|}
\hline & \multicolumn{4}{|c|}{ MALES $(N=9)$} & \multicolumn{4}{|c|}{ FEMALES $(\mathrm{N}=14)$} \\
\hline & $\overline{\boldsymbol{x}}$ & Min & Max & SD & $\overline{\boldsymbol{x}}$ & Min & Max & SD \\
\hline Snout-vent length (SVL) & 41.2 & 37.5 & 44.9 & 2.6 & 61.6 & 51.0 & 81.9 & 8.9 \\
\hline Head length & 17.8 & 15.6 & 19.4 & 1.2 & 26.0 & 21.5 & 32.6 & 3.3 \\
\hline Head width & 17.4 & 15.0 & 19.5 & 1.3 & 27.1 & 21.7 & 37.2 & 4.3 \\
\hline Eye diameter & 5.4 & 4.8 & 6.6 & 0.5 & 7.6 & 6.4 & 9.6 & 0.8 \\
\hline Eye-nostril distance & 5.4 & 4.5 & 6.1 & 0.5 & 7.7 & 6.4 & 9.4 & 0.8 \\
\hline Tympanum diameter & 2.4 & 1.8 & 2.8 & 0.3 & 3.2 & 2.7 & 4.3 & 0.4 \\
\hline Upper eyelid width & 4.3 & 3.2 & 4.9 & 0.5 & 5.9 & 4.8 & 7.2 & 0.6 \\
\hline Interorbital distance & 4.3 & 3.6 & 5.4 & 0.6 & 6.6 & 4.9 & 9.0 & 1.1 \\
\hline Internarial distance & 3.5 & 3.3 & 3.9 & 0.3 & 5.0 & 4.2 & 6.6 & 0.6 \\
\hline Nostril-tip of snout distance & 2.8 & 1.5 & 3.4 & 0.6 & 4.3 & 2.3 & 5.8 & 0.9 \\
\hline Thigh length & 20.6 & 14.4 & 23.9 & 2.8 & 31.3 & 25.4 & 36.7 & 3.9 \\
\hline Tibia length & 22.1 & 19.2 & 24.6 & 1.8 & 31.6 & 23.5 & 38.5 & 4.4 \\
\hline Foot length & 30.8 & 26.6 & 34.5 & 2.4 & 44.6 & 35.9 & 53.4 & 6.0 \\
\hline Length of finger I & 7.5 & 6.4 & 8.5 & 0.6 & 11.9 & 9.0 & 15.1 & 2.0 \\
\hline Length of finger II & 4.9 & 4.3 & 5.9 & 0.5 & 7.0 & 4.5 & 8.8 & 1.0 \\
\hline Head width/SVL & 0.42 & 0.38 & 0.46 & 0.02 & 0.44 & 0.42 & 0.47 & 0.01 \\
\hline Head length/SVL & 0.43 & 0.40 & 0.46 & 0.01 & 0.42 & 0.39 & 0.44 & 0.01 \\
\hline Tympanum diameter/SVL & 0.06 & 0.04 & 0.07 & 0.00 & 0.05 & 0.04 & 0.06 & 0.00 \\
\hline Eye diameter/SVL & 0.13 & 0.11 & 0.14 & 0.00 & 0.12 & 0.11 & 0.14 & 0.00 \\
\hline Eye diameter/Tympanum diameter & 2.29 & 1.84 & 2.66 & 0.25 & 2.38 & 2.04 & 2.66 & 0.18 \\
\hline Tight length/SVL & 0.53 & 0.49 & 0.58 & 0.02 & 0.51 & 0.43 & 0.56 & 0.03 \\
\hline Tibia length/SVL & 0.53 & 0.49 & 0.58 & 0.02 & 0.51 & 0.44 & 0.57 & 0.03 \\
\hline Tight length + Tibia length & 42.7 & 33.6 & 48.5 & 4.48 & 62.9 & 49.7 & 74.2 & 8.3 \\
\hline Tight length + Tibia length/SVL & 1.03 & 0.86 & 1.13 & 0.08 & 1.02 & 0.87 & 1.14 & 0.07 \\
\hline
\end{tabular}



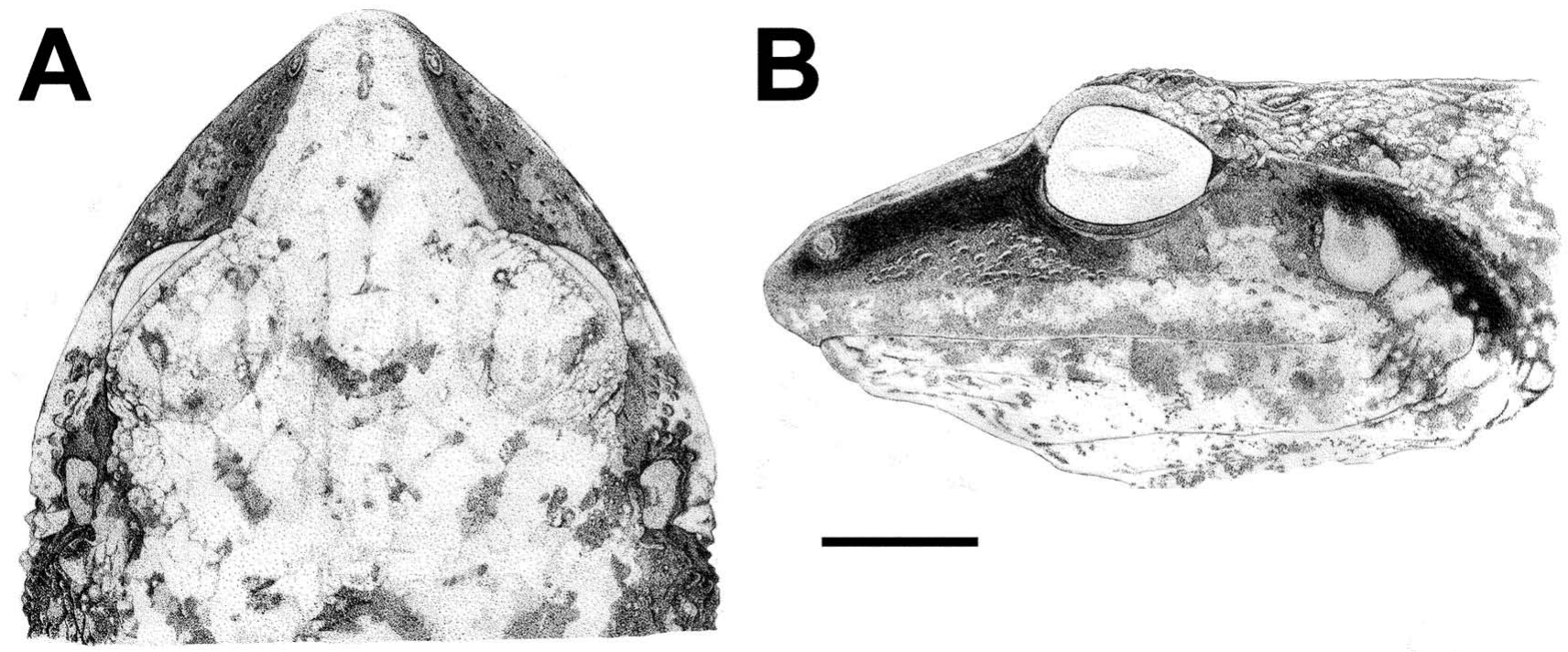

FIGURE 3. Strabomantis aramunha UFBA 6221, adult female. (A) Dorsal and (B) lateral views of head. Bar equals 6 mm. Line drawings Rafael 0. Abreu.
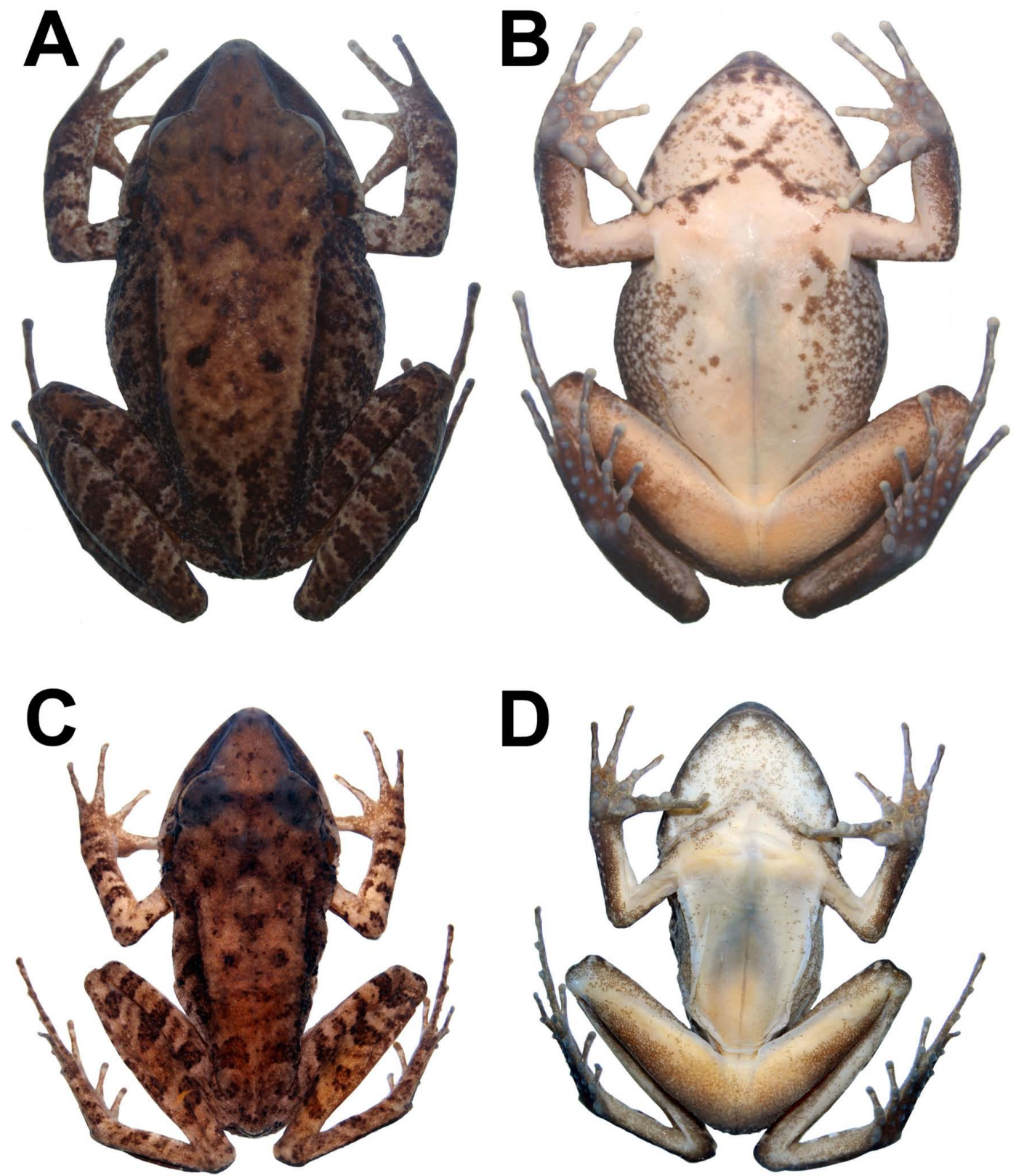

FIGURE 4. Strabomantis aramunha. (A) Dorsal and (B) ventral views of UFBA 6221, adult female, SVL $66.1 \mathrm{~mm}$. (C) Dorsal and (D) ventral views of MZUEFS 2125, adult male, SVL $36.6 \mathrm{~mm}$ (photo by Marcelo F. Napoli). 

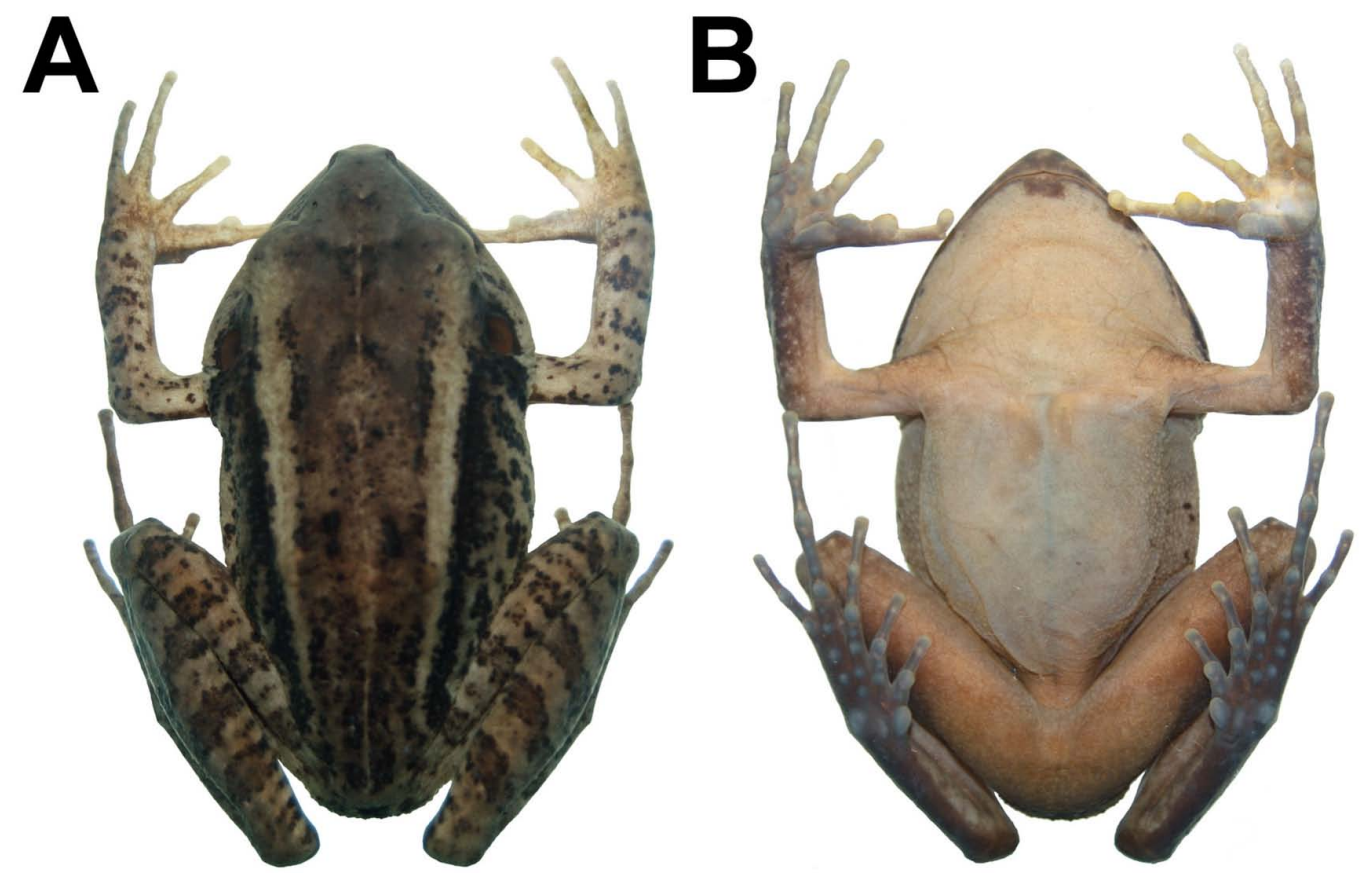

FIGURE 5. Strabomantis aramunha. (A) Dorsal and (B) ventral views of UFBA 5971, adult female, SVL 66.6 mm (photo by Marcelo F. Napoli).

ACKNowledgments: We are grateful to Alessandra Silva de Santana, Ariane Lima Xavier, Ednei Almeida Mercês, Milena Camardelli, Patricia Mendes Fonseca, Roseane Santiago, Thaís Andrade Ferreira Dória, and Wilton Fahing for field assistance. We acknowledge Zélis Pereira for allowing us to access areas under his care and for logistic assistance at Parque Estadual das Sete Passagens. This study was supported by the projects 'Anurofauna da Serra do Sincorá e Serra do Rio de Contas, Chapada Diamantina' (Conselho Nacional de Desenvolvimento Científico e Tecnológico [CNPq], proc. no. 475020/2004-9 and 304507/2005-9) and 'Plano de Manejo do Parque Estadual das Sete Passagens' (Secretaria de Meio Ambiente e Recursos Hídricos [SEMARH] and Companhia de Eletricidade do Estado da Bahia [COELBA]). CNPq provided fellowship for MFN (Proc. 302542/2008-6).

\section{LITERATURE CITED}

Cassimiro, J. 2009. Strabomantis aramunha. In IUCN 2009. IUCN Red List of Threatened Species. Version 2009.2. Electronic database accessible at http://www.iucnredlist.org. Captured on 19 December 2009.

Cassimiro, J., V.K. Verdade and M.T. Rodrigues. 2008. A large and enigmatic new eleutherodactyline frog (Anura, Strabomantidae) from Serra do Sincorá, Espinhaço range, Northeastern Brazil. Zootaxa 1761: 59-68.

Frost, D.R. 2009. Amphibian Species of the World: an Online Reference. Version 5.3 (12 February, 2009). Electronic Database accessible at http://research.amnh.org/herpetology/amphibia. American Museum of Natural History, New York, USA. Captured on 19 December 2009.

Rizzini, C.T. 1979. Tratado de Fitogeografia do Brasil. Aspectos sociológicos e florísticos. São Paulo: EDUSP/HUCITEC. 374 p.

RECEIVED: January 2010

REVISED: February 2010

ACCEPTED: March 2010

PUBLISHED ONLINE: May 2010

EDITORIAL RESPONSIBILITY: Victor G. Dill Orrico 